\title{
Health locus Of CONTROL AMONG PATIENTS WITH TYPE 2 DIABETES - PRELIMINARY TEST RESULTS
}

\author{
Katarzyna Anna Czyżowicz ${ }^{1, A, C, D, E, F}$, Katarzyna Wojtas ${ }^{1, A, C, D, E}$, Justyna Szydło ${ }^{2, B, C, D}$, Patrycja Zurzycka ${ }^{1, C, D, E}$
}

'Department of Clinical Nursing, Institute of Nursing and Midwifery, Faculty of Health Sciences, Jagiellonian University Medical College, Krakow, Poland

2J. Dietl Specialist Hospital in Krakow, Poland

Authors' contribution:

A. Study design/planning $\bullet$ B. Data collection/entry $\bullet$ C. Data analysis/statistics $\bullet$ D. Data interpretation $\bullet$ E. Preparation of manuscript $\bullet$ F. Literature analysis/search $\bullet$ G. Funds collection

\author{
Address for correspondence: \\ Katarzyna Anna Czyżowicz \\ Department of Clinical Nursing \\ Institute of Nursing and Midwifery \\ Faculty of Health Sciences \\ Jagiellonian University Medical College \\ 25 Kopernika St. \\ 30-501 Krakow, Poland \\ e-mail: katarzyna.czyzowicz@uj.edu.pl \\ SUBMITTED: 22.08.2019 \\ ACCEPTED: 27.09 .2019 \\ DOI: https://doi.org/10.5114/ppiel.2019.92539
}

\begin{abstract}
Introduction: Diabetes is an increasing problem of contemporary societies. In chronic diseases, the patient's approach has a significant impact on self-care, treatment, and prevention of complications. It is related to the concept of internal or external health locus of control.

Aim of the study: The aim of the study was to investigate health locus of control among type 2 diabetes patients. Material and methods: The study involved 70 patients with type 2 diabetes, hospitalised in the Clinical Department of Metabolic Diseases at the University Hospital in Krakow. The Multidimensional Health Locus of Control scale (MHLC) - version B and the authors' questionnaire were used to examine the health locus of control. Statistical analysis was carried out using Statistica 13.1, and $p<0.05$ was the significance level.

Results: The highest result was obtained in the area of locus of control in the external dimension - the influence of other people, followed by the internal dimension. The lowest result was obtained in the area of health locus of control in chance. Locus of health control in the external dimension correlated with the age and education level of the respondents and the support they received, as well as with their reactions to the diagnosis. Both the internal and external dimensions of health locus of control correlated with the knowledge of the respondents about hypoglycaemia and hyperglycaemia. Conclusions: The results of our own research indicate the necessity of taking actions aimed at strengthening the internal sense of health control in patients with type 2 diabetes.
\end{abstract}

Key words: health locus of control, patient, type 2 diabetes.

\section{INTRODUCTION}

Diabetes is a group of chronic metabolic diseases caused by abnormalities in the production of the in sulin hormone by the B-cells of the Langerhans islands and/or a defect in its operation. The most characteristic symptom for this disease is increased level of glucose in blood [1]. Year by year, the number of people with diabetes is constantly growing, which is why it is counted among the civilisation diseases of the 21st century. According to data published by the Central Statistical Office in 2017, more than 2.1 million people aged over 15 years suffer from this disease in Poland. Over half of them, i.e. around 1.2 million, are people aged 30-69 years [2]. All over the world, according to data published by the World Health Organisation (WHO), there are 350 million people living with diabetes. According to the calculations made by the WHO, by 2030 diabetes will be the seventh most common cause of death in the world [3].

The main reason for the development of type 2 diabetes is an unhealthy lifestyle, which includes, among others: a diet rich in simple carbohydrates and saturated fat, lack of physical activity, smoking, and excessive alcohol consumption [1].

Unbalanced blood glucose level caused by the lack of constant disease control or failure to follow the instructions of a specialist physician in the early phase of the disease are the main factors that can lead to a number of serious, but also life-threatening, complications including: stroke, ischaemic heart disease, as well as disturbances in the proper functioning of eyes (retinopathy), kidneys (nephropathy), and peripheral nerves (neuropathy) [1].

In chronic diseases, healthy lifestyle, self-control, and following a doctor's recommendations have a great 
influence on the results of treatment and prevention of complications. The human approach to one's own health, the awareness of responsibility for it, and the sense to which this responsibility can be transferred to third parties also play an important role.

The concept of stressing the important role of the approach to one's own health is closely related to the theory of locus of control, created by the American psychologist Julian Rotter. He distinguished internal and external sense of locus of control over a given situation. People who are characterised by an internal locus of control feel that they themselves are the creators of a given situation in their lives and only they have an impact on its course. People characterised by an external locus of control believe that other people have an impact on events in their lives or that what is happening is simply a matter of chance or fate [4-6].

Two people are closely related to J. Rotter's assumptions: Kenneth and Barbara Wallston - the authors of the theory of health locus of control. According to them, there is a correlation between two variables: the locus of health control and the actions taken to be healthy [5]. People with an internal locus of health control feel responsible for their health and think that the fact that they are healthy is primarily their merit. It is also suggested that people with internal locus of health control are not only more willing to follow the doctor's recommendations, but also use other sources that will allow them to deepen their knowledge about the disease in order to maintain health in the best possible form. In addition, they are more likely to live a healthy lifestyle [5-9].

People with an external locus of health control believe that illness is a matter of fate and avoid taking responsibility for their own health, they tend to claim that they do not have any influence on it; only health professionals (doctors, nurses) or other people can keep their health at an appropriate level. They often entrust the fact of whether they remain healthy or become ill to chance [5-9].

Diabetes is a disease that can develop unnoticed for many years, often leading to irreversible complications, that is why it is very important to educate the public in this area, to increase public awareness that self-control, regular examinations, and visits to the doctor reduce the risk of morbidity, help to detect the disease at an early stage, and avoid complications.

\section{AIM OF THE STUDY}

The aim of the study was to investigate the locus of health control among patients with type 2 diabetes.

\section{MATERIAL AND METHODS}

The research was carried out from April to September 2018 among people diagnosed with type 2 diabe- tes, hospitalised in the Clinical Department of Metabolic Diseases at the University Hospital in Krakow.

The criterion excluding people from the study was: age below 35 and above 64 years, hospitalisation lasting less than three days, radical treatment of diabetes complications (amputation of feet/lower limbs), coexistence of neoplastic disease, occurrence of dementia, and lack of willingness to participate in the study.

The Bioethics Committee of the Jagiellonian University gave a positive decision to carry out the research (Opinion No. 1072.6120.192.2017 dated: 26.10.2017).

The study included 70 participants: 30 women (42.9\%) and 40 men (57.1\%), aged $36-64$ years. The average age was $55.66 \pm 7.03$ years. In the study group there were 41 people (58.6\%) living in urban areas and 29 people $(41.4 \%)$ living in the countryside. Basic vocational education was held by 30 participants (42.9\%), people with secondary education comprised 20 (28.6\%), while those with higher education comprised 10 (14.3\%). Among the respondents there were more people in permanent relationships (52 people - 74.3\%) than those who were single (18 subjects $25.7 \%$ ). Disability benefits as the main source of subsistence were declared by 24 respondents (34.3\%), and slightly fewer were employed (23 people $-32.9 \%$ ). The subjects suffered from diabetes from one month to 30 years. The average duration of the disease in the study group was $10.58 \pm 7.61$ years.

Two research tools were used in the conducted research: the authors' questionnaire and the Multidimensional Health Locus of Control scale (MHLC) - version $\mathrm{B}$. The original questionnaire consisted of 3 groups of questions. The first one included issues related to sociodemographic data (such as: gender, age, marital status, and education). Another group concerned the course of diabetes (including the duration of the disease, circumstances of the diagnosis, currently used treatment, and symptoms). The third group of questions covered issues of the general health situation (including: coexistence of other diseases, consultations with specialists, or hospitalisations).

The Multidimensional Health Locus of Control (MHLC) - version B of Kenneth A. Wallston, Barbara S. Wallston, and Robert De-Vellis in the adaptation of Zygfryd Juczyński contains 18 statements (six for each dimension), thanks to which it is possible to place health locus of control in one of the three dimensions: internal (W scale), influence of others (I scale), or chance ( $P$ scale). Respondents could refer to the statements using a six-point scale (points from 1 to 6 ). In each of the MHLC-B subscales, subjects could get from 6 to 36 points. Higher scores meant stronger redirection of health control to a given area - internal control, location in other people, or in chance [10].

The statistical analysis of the collected material was carried out using the Statistica 13.1 package. Com- 
patibility of distributions of the tested variables with the normal distribution was verified by the ShapiroWilk test. For most numerical variables, descriptive statistics were calculated: average, standard deviation, median, minimum, maximum, and the first and third quartiles. The assessment of differences in the average level of the numerical feature in the two populations was calculated based on the Mann-Whitney $U$ test. The Kruskal-Wallis ANOVA test determined the assessment of differences in the average level of a numerical feature in more than two populations. Furthermore, on the basis of Spearman's rank correlation coefficient, the correlation of two variables that did not meet the normality criterion of the distribution was determined. The statistical significance was assumed to be $p<0.05$.

\section{RESULTS}

In the self-study, the highest result was obtained in the area of locating health control in the external dimension - the influence of other people: MHLC-B (I) - $28.34 \pm 6.15$ points. The respondents gave slightly weaker significance to the location of health control in the internal dimension: MHLC-B (W) - $26.09 \pm 6.35$ points. They placed the poorest health control in random events: MHLC-B (P) $-22.57 \pm 5.56$ points (Table 1 ).

There is no correlation between the internal health locus of control and sociodemographic data such as: age, gender, and education. However, health locus of control in a third person (other people - e.g. doctors, nurses, people close to the patient) correlated with variables such as: age, education, and support received from parents or parents-in-law. Assigning health control to chance was significantly associated with sociodemographic data such as: age and support received from siblings or spouses.

The education of the respondents turned out to be related to health locus of control - the higher the level of education the respondents had, the less they positioned their health control in third parties $(p=0.013)$. Also, respondents who declared support received from parents or parents-in-law were less likely to place their health locus of control in third parties, compared to respondents who did not have such support $(p=0.023)$.

Patients who did not receive support from siblings or spouses were more likely to place their health locus of control in chance, in comparison with those who had such support $(p=0.006)$.

The study of the age correlation of subjects with the results of MHLC scale showed that the older the respondents, the more they positioned their health locus of control in third parties. Elderly people more often placed health locus of control in chance (Table 2).

Patients who felt despair and/or anxiety after the diagnosis showed a higher sense of health locus of control in other people (Table 3).

Table 1. Results of health locus of control in the MHLC-B scale

\begin{tabular}{|c|c|c|c|c|c|c|c|}
\hline \multirow{2}{*}{$\begin{array}{l}\text { Health locus of control } \\
\text { (dimension) }\end{array}$} & \multicolumn{7}{|c|}{ Results of the MHLC-B scale } \\
\hline & $\bar{x}$ & SD & Me & Min. & Max. & Q1 & Q3 \\
\hline Internal (W) & 26.09 & 6.35 & 27.00 & 6.00 & 36.00 & 23.00 & 23.00 \\
\hline Influence of others (I) & 28.34 & 6.15 & 30.00 & 6.00 & 36.00 & 25.00 & 25.00 \\
\hline Chance (P) & 22.57 & 5.56 & 23.00 & 6.00 & 36.00 & 20.00 & 20.00 \\
\hline
\end{tabular}

Table 2. Age and health locus of control in other people and chance

\begin{tabular}{lccc}
\hline Sociodemographic variable & $\begin{array}{c}\text { Health locus of control } \\
\text { (dimension) }\end{array}$ & $\begin{array}{c}\text { The results of Spearman's } \\
\text { correlation test }(r)\end{array}$ & $\begin{array}{c}\text { Level of statistical } \\
\text { significance }(p)\end{array}$ \\
\hline Age & Influence of others $(I)$ & 0.24 & 0.049 \\
\cline { 2 - 4 } & Chance $(P)$ & 0.33 & 0.006 \\
\hline
\end{tabular}

Table 3. Reactions of the subjects after the diagnosis of the disease and health locus of control in other people

\begin{tabular}{lcccccccccc}
\hline Type of reaction & & \multicolumn{7}{c}{ MHLC-B scale results - influence of others (I) } \\
\cline { 3 - 9 } & & $\bar{x}$ & SD & Me & Min. & Max. & Q1 & Q3 & $p$ \\
\hline \multirow{2}{*}{ Despair } & Yes & 34.67 & 1.53 & 35.00 & 33.00 & 36.00 & 33.00 & 36.00 & 0.022 \\
& No & 28.06 & 6.13 & 30.00 & 6.00 & 36.00 & 24.00 & 33.00 & \\
\hline \multirow{2}{*}{ Anxiety } & Yes & 30.34 & 5.02 & 32.00 & 15.00 & 36.00 & 27.00 & 34.00 & 0.011 \\
& No & 26.93 & 6.54 & 29.00 & 6.00 & 36.00 & 24.00 & 31.00 & \\
\hline
\end{tabular}

$\overline{\bar{x}}$ - arithmetic average, SD - standard deviation, Me - median, Min. - minimum, Max. - maximum, Q1 - lower quartile, Q3 - upper quartile 
People who indicated sweating and/or malaise as a symptom of hypoglycaemia had a higher sense of internal health locus of control. Respectively, the respondents who indicated accelerated heartbeat as a symptom of hypoglycaemia had a lower sense of internal health locus of control. Respondents indicating a feeling of strong hunger and/or loss of consciousness as a symptom of hyperglycaemia had a lower sense of internal health locus of control (Table 4).

Subjects who had a stronger sense of health locus of control in others considered sweating to be a symptom of hypoglycaemia. Whereas, those who considered difficulties with concentration and/or dry mucous membranes to be its symptom had a weaker sense of health locus of control in other people. Somnolence and/or coma and/or weakness as symptoms of hyperglycaemia were indicated by respondents with a weaker sense of health locus of control in other people (Table 5).

Respondents who considered coma and/or somnolence and/or loss of consciousness as symptoms of hypoglycaemia, as well as those who considered pruritus of the skin as a symptom of hyperglycaemia, had a weaker sense of health locus of control in chance (Table 6).

Table 4. Symptoms of hypoglycaemia and hyperglycaemia indicated by the subjects and internal location of health control

\begin{tabular}{|c|c|c|c|c|c|c|c|c|c|}
\hline \multirow{2}{*}{$\begin{array}{l}\text { Symptoms indicated } \\
\text { by the respondents }\end{array}$} & & \multicolumn{8}{|c|}{ MHLC-B results - internal dimension (W) } \\
\hline & & $\bar{x}$ & SD & Me & Min. & Max. & Q1 & Q3 & $p$ \\
\hline \multicolumn{10}{|l|}{ Hypoglycaemia } \\
\hline \multirow[t]{2}{*}{ Sweating } & Yes & 28.17 & 5.00 & 28.00 & 20.00 & 36.00 & 24.00 & 32.00 & 0.010 \\
\hline & No & 24.00 & 6.92 & 26.00 & 6.00 & 34.00 & 21.00 & 29.00 & \\
\hline \multirow[t]{2}{*}{ Malaise } & Yes & 28.33 & 4.99 & 29.00 & 20.00 & 36.00 & 24.00 & 32.00 & 0.008 \\
\hline & No & 24.08 & 6.81 & 25.00 & 6.00 & 36.00 & 21.00 & 28.00 & \\
\hline \multirow[t]{2}{*}{ Accelerated heartbeat } & Yes & 24.59 & 5.04 & 24.00 & 18.00 & 35.00 & 20.00 & 28.00 & 0.018 \\
\hline & No & 26.57 & 6.69 & 28.00 & 6.00 & 36.00 & 24.00 & 31.00 & \\
\hline \multicolumn{10}{|l|}{ Hyperglycaemia } \\
\hline \multirow{2}{*}{$\begin{array}{l}\text { The feeling of strong } \\
\text { hunger }\end{array}$} & Yes & 21.73 & 8.66 & 24.00 & 6.00 & 34.00 & 18.00 & 27.00 & 0.046 \\
\hline & No & 26.90 & 5.55 & 28.00 & 8.00 & 36.00 & 23.00 & 31.00 & \\
\hline \multirow[t]{2}{*}{ Loss of consciousness } & Yes & 18.50 & 8.39 & 22.00 & 6.00 & 24.00 & 14.00 & 23.00 & 0.032 \\
\hline & No & 26.55 & 5.99 & 27.00 & 6.00 & 36.00 & 23.00 & 31.00 & \\
\hline
\end{tabular}

$\overline{\bar{x}}$ - arithmetic average, SD - standard deviation, Me - median, Min. - minimum, Max. - maximum, Q1 - lower quartile, Q3 - upper quartile

Table 5. Symptoms of hypoglycaemia and hyperglycaemia indicated by the respondents and health locus of control in other people

\begin{tabular}{|c|c|c|c|c|c|c|c|c|c|}
\hline \multirow{2}{*}{$\begin{array}{l}\text { Symptoms indicated } \\
\text { by the respondents }\end{array}$} & & \multicolumn{8}{|c|}{ MHLC-B scale results - influence of others (I) } \\
\hline & & $\bar{x}$ & SD & Me & Min. & Max. & Q1 & Q3 & $p$ \\
\hline \multicolumn{10}{|l|}{ Hypoglycaemia } \\
\hline \multirow[t]{2}{*}{ Sweating } & Yes & 30.09 & 4.42 & 30.00 & 22.00 & 36.00 & 27.00 & 34.00 & 0.041 \\
\hline & No & 26.60 & 7.15 & 27.00 & 6.00 & 36.00 & 24.00 & 32.00 & \\
\hline \multirow{2}{*}{$\begin{array}{l}\text { Difficulties with } \\
\text { concentration }\end{array}$} & Yes & 26.70 & 5.74 & 27.00 & 15.00 & 36.00 & 23.00 & 31.00 & 0.040 \\
\hline & No & 29.15 & 6.24 & 31.00 & 6.00 & 36.00 & 27.00 & 34.00 & \\
\hline \multirow{2}{*}{$\begin{array}{l}\text { Dryness of mucous } \\
\text { membranes }\end{array}$} & Yes & 17.67 & 10.12 & 23.00 & 6.00 & 24.00 & 6.00 & 24.00 & 0.021 \\
\hline & No & 28.82 & 5.57 & 30.00 & 8.00 & 36.00 & 25.00 & 33.00 & \\
\hline \multicolumn{10}{|l|}{ Hyperglycaemia } \\
\hline \multirow[t]{2}{*}{ Somnolence } & Yes & 26.24 & 4.99 & 25.00 & 16.00 & 34.00 & 23.00 & 30.00 & 0.007 \\
\hline & No & 29.24 & 6.42 & 31.00 & 6.00 & 36.00 & 27.00 & 34.00 & \\
\hline \multirow[t]{2}{*}{ Coma } & Yes & 25.00 & 4.92 & 24.50 & 16.00 & 32.00 & 23.00 & 30.00 & 0.016 \\
\hline & No & 28.90 & 6.19 & 30.50 & 6.00 & 36.00 & 26.00 & 33.00 & \\
\hline \multirow[t]{2}{*}{ Weakness } & Yes & 25.80 & 7.43 & 25.00 & 6.00 & 36.00 & 21.50 & 31.00 & 0.038 \\
\hline & No & 29.36 & 5.31 & 31.00 & 8.00 & 36.00 & 27.00 & 33.00 & \\
\hline
\end{tabular}

$\overline{\bar{x}}$ - arithmetic average, SD - standard deviation, Me - median, Min. - minimum, Max. - maximum, Q1 - lower quartile, Q3 - upper quartile 
HEALTH LOCUS OF CONTROL AMONG PATIENTS WITH TYPE 2 DIABETES - PRELIMINARY TEST RESULTS

Table 6. Symptoms of hypoglycaemia and hyperglycaemia indicated by the respondents and health locus of control in chance

\begin{tabular}{|c|c|c|c|c|c|c|c|c|c|}
\hline \multirow{2}{*}{$\begin{array}{l}\text { Symptoms indicated } \\
\text { by the respondents }\end{array}$} & & \multicolumn{8}{|c|}{ MHLC-B scale results - chance (P) } \\
\hline & & $\bar{x}$ & SD & Me & Min. & Max. & Q1 & Q3 & $p$ \\
\hline \multicolumn{10}{|l|}{ Hypoglycaemia } \\
\hline \multirow[t]{2}{*}{ Coma } & Yes & 20.05 & 6.08 & 21.00 & 6.00 & 30.00 & 17.00 & 23.00 & 0.025 \\
\hline & No & 23.51 & 5.10 & 24.00 & 10.00 & 36.00 & 21.00 & 27.00 & \\
\hline \multirow[t]{2}{*}{ Somnolence } & Yes & 20.10 & 6.87 & 21.00 & 6.00 & 36.00 & 14.50 & 23.50 & 0.023 \\
\hline & No & 23.56 & 4.66 & 24.00 & 10.00 & 31.00 & 21.00 & 27.00 & \\
\hline \multirow[t]{2}{*}{ Loss of consciousness } & Yes & 19.83 & 5.18 & 20.00 & 10.00 & 28.00 & 17.00 & 24.00 & 0.010 \\
\hline & No & 23.52 & 5.41 & 24.00 & 6.00 & 36.00 & 21.00 & 27.50 & \\
\hline \multicolumn{10}{|l|}{ Hyperglycaemia } \\
\hline \multirow[t]{2}{*}{ Pruritus of the skin } & Yes & 20.42 & 5.73 & 21.00 & 6.00 & 30.00 & 18.00 & 24.00 & 0.034 \\
\hline & No & 23.37 & 5.33 & 24.00 & 10.00 & 36.00 & 21.00 & 27.00 & \\
\hline
\end{tabular}

$\overline{\bar{x}}$ - arithmetic average, SD - standard deviation, Me - median, Min. - minimum, Max. - maximum, Q1 - lower quartile, Q3 - upper quartile

\section{DISCUSSION}

According to the theory of health locus of control, there is a correlation between health locus of control and activities undertaken for maintaining one's health. Therefore, the locus of control is the key factor influencing the person's interest in their health and involvement in the treatment process [5]. Patients with an internal health locus of control achieve better treatment results, and they apply the guidelines given to them by the therapeutic team better - often undertaking independent preventive or therapeutic activities. In addition, they closely observe their bodies and do not underestimate the emerging worrying or pathological symptoms associated with a change in health $[4-6,8,9]$. On the other hand, people with external health locus of control minimise their own influence on their condition, often downplaying or negating worrying symptoms of disorders and developing disease. These patients are passive in both their care for their health and in coping with the disease, seeking solutions to their health problems in external factors - other people, such as medical staff, or chance $[4,6,7,9]$.

Diabetes, like many other chronic diseases, requires a sick person to lead a healthy lifestyle, systematic self-control, periodic visits to specialist doctors, and following their recommendations. Observance of these rules not only positively affects the outcome of the therapeutic process, but also prevents or allows for early detection of dangerous complications. Thus, sense of health locus of control influences the means of coping with chronic disease [8, 11].

The authors' own research show that among respondents, health locus of control in the external dimension prevailed - the influence of others, followed by health locus of control in the internal dimension, and the weakest location was observed chance. Similar results were obtained by Kurpas et al. in their re- search. They showed that people with diabetes most often placed health locus of control in the external dimension, and the chance was identified as the least significant impact [12]. The results of research carried out by Basińska et al., in which the respondents placed the strongest health locus of control in the internal dimension, and the weakest in the chance [13], are different. Similar results were presented in the research conducted by Klinovszky et al., where the respondents most strongly indicated the important role of internal health control; secondly, they located health control in other people, and lastly in chance [14].

The studies of Basińska et al. showed that patients with type 1 diabetes, in comparison with healthy people, show a stronger health locus of control in other people. However, there were no differences in the internal health locus of control and the health locus of control in chance [15]. A significantly more detailed study was conducted by Mućko et al., in which an analysis of health locus of control was made taking into account the type of diabetes. In the case of internal control, there were no significant differences between patients with type 1 and type 2 diabetes. However, there was a significant discrepancy in the external health locus of control among those with type 1 diabetes. People with type 2 diabetes presented weaker location in external control than patients with type 1 diabetes. In addition, patients with type 2 diabetes compared to those with type 1 had a weaker belief that chance plays an important role in health locus of control [8].

The results of the authors' own studies did not show any connection between the result of the MHLC-B scale (W) - internal health locus of control (W) and sociodemographic data (age, sex, education). The health locus of control in other people - MHLC-B (I), correlated with such variables as: age, education, and support received from parents or parents-in-law. 
Respectively, the result of the MHLC-B (P) scale - the impact of chance, was associated with such sociodemographic data as age and support received from siblings or spouses. Juczyński came to similar conclusions in his research, stating that with age, the sense of internal control over health weakens, and at the same time the conviction about the significant influence of others and chance is reinforced [10]. Studies by Basińska et al. also showed that the more advanced the age of people with diabetes, the more they place health locus of control in other people [13]. Similar conclusions are also drawn from the results of studies by Mućko et al. It was observed that belief in the impact of chance on health increased with patient's age [8].

The analysis of available scientific studies and the authors' own research draw attention to the great importance of the issues raised and the need to undertake further research in this area.

\section{CONCLUSIONS}

The health locus of control in other people was dominant among patients with type 2 diabetes (external dimension).

The results of the authors' own research indicate the necessity of taking actions aimed at strengthening the internal sense of health control in patients with type 2 diabetes.

\section{Disclosure}

The authors declare no conflict of interest.

\section{References}

1. Zalecenia kliniczne dotyczące postępowania u chorych na cukrzycę 2018 - Stanowisko Polskiego Towarzystwa Diabetologicznego. Diabetol Prakt 2018; 4: 1-20.

2. Główny Urząd Statystyczny. Infografika - Światowy Dzień Walki z Cukrzycą - 14.11.2016 [Accessed: 09.10.18].

3. World Health Organization/Europe - News [Accessed: 09.10.18].

4. Drwal Ł. Poczucie kontroli jako wymiar osobowości - podstawy teoretyczne, techniki badawcze i wyniki badań. W: Brzozowski P (ed.). Adaptacja kwestionariuszy osobowości. Wydawnictwo Naukowe PWN, Warszawa 1995; 199-227.

5. Wajrak A, Włoszczak-Szubzda A. Poczucie umiejscowienia kontroli a podejmowanie zachowań zdrowotnych przez pacjentów z chorobami tarczycy. Aspekty Zdrowia i Choroby 2018; 3: 71-90.

6. Borys B. Zasoby zdrowotne w psychice człowieka. Forum Med Rodz 2010; 4: 44-52.

7. Kurowska K, Manys K. Poczucie własnej skuteczności a umiejscowienie kontroli zdrowia w grupie osób z rozpoznaniem nadciśnienia tętniczego. Pol Prz Nauk Zdr 2016; 3: 239-245.

8. Mućko P, Kokoszka A, Skłodowska Z. Porównanie stylów radzenia sobie z chorobą, występowania objawów depresyjnych i lękowych oraz lokalizacji poczucia kontroli $u$ chorych na cukrzyce typu 1 i 2. Diabetol Prakt 2005; 6: 240-249.
9. Sak J, Jarosz M, Mosiewicz J, et al. Postrzeganie własnej choroby a poczucie odpowiedzialności za swoje zdrowie osób przewlekle chorych. Med Og Nauk Zdr 2011; 17: 169-173.

10. Juczyński Z. Narzędzia pomiaru w promocji i psychologii zdrowia. Pracownia Testów Psychologicznych Polskiego Towarzystwa Psychologicznego, Warszawa 2012; 183.

11. Kurowska K, Toś M. Poczucie własnej skuteczności a zachowania zdrowotne w grupie osób z rozpoznaniem cukrzycy typu 2. Pol Prz Nauk Zdr 2017; 1: 31-37.

12. Kurpas D, Kusz J, Jedynak T, et al. Umiejscowienie kontroli zdrowia u osób ze schorzeniami przewlekłymi. Fam Med Primary Care Rev 2012; 14: 186-188.

13. Basińska M, Zalewska-Rydzkowska D, Junik R, et al. Przewidywanie stosowania się do zaleceń dietetycznych przez chorych na cukrzycę typu 1 - związek z umiejscowieniem kontroli zdrowia. Diabetol Prakt 2007; 8: 419-424.

14. Klinovszky A, Kiss I, Papp-Zipernovszky O, et al. Associations of different adherences in patients with type 2 diabetes mellitus. Patient Prefer Adherence 2019; 13: 395-407.

15. Basińska M, Maćkowska P, Listwan A. Przekonania o umiejscowieniu kontroli zdrowia chorych na cukrzycę typu 1 a zachowania zdrowotne. Diabetol Prakt 2011; 12: 151-159. 